American Journal of Immunology 1 (3): 119-124, 2005

ISSN 1553-619X

(c) 2005 Science Publications

\title{
Soluble Tumor Necrosis Factor Receptor Type I and Dranulysin as Immunological Markers in Congestive Heart Failure
}

\author{
${ }^{1}$ Simone de Lima e Silva Deo, ${ }^{3}$ Maria do Carmo Valente de Crasto, ${ }^{2}$ Alda Maria Da-Cruz, ${ }^{4}$ Milton Ozório \\ Moraes, ${ }^{4}$ Alexandre Pio Abreu, ${ }^{1}$ Jorge Luiz Alves, ${ }^{1}$ Carlos Roberto Alves \\ Fundação Oswaldo Cruz/Instituto Oswaldo Cruz - ${ }^{1}$ Departamento de Bioquímica e Biologia Molecular, \\ ${ }^{2}$ Departamento de Imunologia and ${ }^{4}$ Departamento de Micobacterioses - Av. Brasil n ${ }^{\circ} 4365$, CP 926, 21040-900, \\ Manguinhos, Rio de Janeiro-RJ/Brasil. \\ ${ }^{3}$ Universidade Federal do Estado do Rio de Janeiro, Hospital Universitário Gaffrée e Guinle (HUGG/UNIRIO), Rua \\ Mariz e Barros n 775, 20270-004, Tijuca, Rio de Janeiro-RJ/Brasil.
}

\begin{abstract}
Previous studies have shown that circulating levels of cytokines are increased in patients with congestive heart failure (CHF), resulting in myocardial depression. In this work, we have determined serum levels of TNF- $\alpha$ and IFN- $\gamma$ by ELISA, detected sTNFR-I by dot ELISA, as well as TNF $\alpha$, IL-6, IL-10 and granulysin mRNA in unstimulated peripheral blood mononuclear cells (PBMC) by RT-PCR in CHF patients. Such patients were classified using New York Heart Association criteria and compared to a control group of volunteers without CHF. The performed echocardiographic evaluations showed a significant difference between the control group and the patients. Additionally, the ejection fraction and the left ventricular fractional shortening showed a direct relation with functional classes, varying in inverse proportion. Generally, the studied cytokines in serum or PBMC did not correlate either to functional classes or to the presence/absence of CHF. However, the granulysin mRNA was detected in most of the patients tested as compared to controls. Moreover, the qualitative detection of the sTNFR-I also made it possible to discriminate between patients and the control group. Functional classes could be separated because of a direct association between CHF severity and elevated levels of sTNFR-I, defined by intensity of signal in dot-ELISA. Our results suggest that detection of granulysin mRNA as well as the detection of sTNFR-I appear to have a clinical relevance as markers of immune activation in CHF.
\end{abstract}

Keywords: congestive heart failure, echocardiography, cytokines, IL-6, IL-10, TNF- $\alpha$, sTNFR-I, granulysin

\section{INTRODUCTION}

Traditionally, patients with CHF are treated with diuretics, vasodilators and inotropic drugs, resulting in improvement in functional status and symptoms, but with no reduction in long-term mortality ${ }^{1}$. Several studies have demonstrated that CHF patients are characterized by persistent immune activation. This is indicated by increased circulating levels of inflammatory cytokines such as TNF- $\alpha^{2}$, IL-1 and IL$6^{3}$. Furthermore, studies corroborating the pathogenic role of inflammatory cytokines in CHF were conducted in mouse models ${ }^{4}$.

Cytokines may modulate cardiovascular functions by a variety of mechanisms. Studies indicate that cytokines as TNF $\alpha$ and IL- $1 \beta$ depress the myocardial contractility $^{5}$. This phenomenon may be due to uncoupling of $\beta$-adrenergic signalling, increase in

cardiac nitric oxide synthesis or alterations in intracellular calcium homeostasis ${ }^{6}$. The TNF- $\alpha$ and members of the IL- 6 family may also induce structural changes in the failing myocardium, such as cardiomyocyte hypertrophy and interstitial fibrosis.
Additionally, these cytokines may promote cardiomyocyte apoptosis, activation of metalloproteinases and impairment of the expression of their inhibitors, possibly contributing to cardiac remodelling ${ }^{7}$. It was also demonstrated the expression of TNF- $\alpha$ in myocyte, endothelial cells, intramyocardial cells of vascular smooth muscle and blood vessels in the ventricles of patients with dilated cardiomyopathy ${ }^{8}$. Moreover, it has been shown that the exogenous and endogenous TNF- $\alpha$ may produce myocardial depression and hemodynamic effects in models ${ }^{9}$. In addition, the increased serum levels of IL-6 in patients with $\mathrm{CHF}$ are correlated with low ejection fraction, high right atrial pressures and poor prognosis ${ }^{10}$.

Several studies suggest an increased production of these cytokine and other inflammatory molecules directly associated with the severity of the disease process, according to the New York Heart Association - NYHA ${ }^{11}$. Soluble TNF- $\alpha$ receptors (sTNFR-I and sTNFR-II) have been found to be high in unstable patients, with NYHA classification III and IV, who died during the first month of follow-up ${ }^{12}$. There are not

Corresponding Author: $\quad$ Dr. Carlos Roberto Alves, Fundação Oswaldo Cruz, Instituto Oswaldo Cruz, Departamento de Bioquímica e Biologia Molecular. Av. Brasil 4365, CP 926, 21040-900, Manguinhos, Rio de Janeiro, RJ, Brasil. 
many studies that have determined the prognostic importance of immunoinflammatory markers such TNF- $\alpha$ and other cytokines although patients with lower plasmatic TNF- $\alpha$ levels had a better prognostic than those with higher levels ${ }^{4}$. More recently, it was verified that circulating levels of TNF- $\alpha$, IL- 6 and soluble TNF- $\alpha$ receptors are independent indicators of mortality in CHF patients ${ }^{13}$. Thus, the aim of this study is to detect TNF- $\alpha$, IFN- $\gamma$, IL-6, IL-10, sTNFR-I and granulysin in clinically classified CHF patients from Rio de Janeiro Brazil.

\section{METHODS}

Studied population: Ten CHF patients that attended to HUGG/UNIRIO were surveyed at this research. The legal procedures for patients (P1-P12) and control group (individuals without CHF; C1-C7) study have followed the ethical norms in FIOCRUZ; and the CHF presence and absence were confirmed by clinical and echocardiographic evaluations, using a Hewlett Packard SLEEP 100 CF device. The Ejection Fraction (EF) was calculated by Teichholz method ${ }^{14}$. Some patients were observed in two moments (a/b: P1, P2, P3, P12). Patients were excluded from the study if they had clinical signs of acute infection or if they had severe renal failure, rheumatoid, hepatic, pulmonary disease and the use of antiinflamatory drugs in the last two weeks. Data were analyzed for statistical significance using an unpaired Student's t-test and considered significant at $\mathrm{p}<0.05$.

Quantification of TNF- $\alpha$ and IFN- $\boldsymbol{\gamma}$ : Serum samples from patients and control groups were collected and stored $\left(-70{ }^{\circ} \mathrm{C}\right)$ until the moment of use. TNF- $\alpha$ $(\mathrm{ng} / \mathrm{mL})$ and IFN- $\gamma(\mathrm{pg} / \mathrm{mL})$ levels were determined by an enzyme-linked immunosorbent assay (ELISA) using commercial kits (Genzyme, Cambridge, MA, USA).

Detection of sTNFR by dot-ELISA: Approximately, $20 \mathrm{ng}$ of serum proteins diluted in PBS had been applied to $0.22 \mu \mathrm{m}$ nitrocellulose membrane. After drying, membranes were treated $\left(25^{\circ} \mathrm{C} ; 120\right.$ minutes) with blocking buffer (PBS pH 7.2 with $5 \%$ of skim milk and $0.5 \%$ of Tween-20). The membranes were then incubated (16 hours, $5{ }^{\circ} \mathrm{C}$ ) with monoclonal antibody anti-sTNFR-I or anti-sTNFR-II diluted 1 : 1000 in wash solution (PBS pH 7.2 with $0.05 \%$ Tween-20), and later washed 3 times (for 5 minutes each) with wash solution. In the next step, membranes were incubated $\left(60\right.$ minutes, $\left.25^{\circ} \mathrm{C}\right)$ with goat $\mathrm{IgG}$ antihuman heavy chain conjugated with peroxidase diluted 1:5000 in wash solution and flowed of another washed cycle. The antigen-antibody complex was visualized with $50 \mathrm{~mL}$ of $0.5 \mathrm{M}$ citrate/phosphate (pH 5.0) buffer solution, containing $0.01 \mathrm{~g}$ of diaminobenzidine and
$40 \mathrm{~mL}$ of $\mathrm{H}_{2} \mathrm{O}_{2}$. The reagents and membranes used were form Sigma-Aldrich Co. (St. Louis, Missouri, USA)

RNA extraction: The patients peripheral blood mononuclear cells - PBMC $\left(2 \times 10^{6}\right)$ were lysed with $1 \mathrm{~mL}$ of Trizol (Invitrogen Corporation) and mixed with $200 \mu \mathrm{L}$ of cloroform:isoamyl alchool (24 : 1). After homogenization, the tubes were left to rest for 2 minutes at $25^{\circ} \mathrm{C}$ and further centrifuged $(12000 \mathrm{xg}$, 15 minutes). The aqueous phase was carefully collected and transferred to another tube. Isopropanol $(1: 1)$ was added to the precipitate $\left(-20{ }^{\circ} \mathrm{C}, 30\right.$ minutes $)$. Tubes were then centrifuged (12000 xg, 20 minutes) and the supernatant removed. The pellet was washed with $500 \mu \mathrm{L}$ of ethanol $70 \%$, air-dried and ressuspended in DEPC-water. The concentration was measured spectrofotometrically at $260 \mathrm{~nm}$ while integrity was evaluated by denaturating-agarose gel electrophoresis.

cDNA synthesis and amplification by PCR: One microgram of total RNA was reverse-transcribed with oligo-dT to label the mRNA ( 10 minutes, $55^{\circ} \mathrm{C}$ ). The solution was instantly ice-colded and mixed with $200 \mathrm{U}$ of reverse transcriptase (Invitrogen) in $20 \mu \mathrm{L}$ of first strand buffer $(50 \mathrm{mM}$ of Tris- $\mathrm{HCl} \mathrm{pH} 8.3,75 \mathrm{mM}$ of $\mathrm{KCl}, 3 \mathrm{mM}$ of $\mathrm{MgCl}_{2}$, and freshly diluted DTT to $10 \mathrm{mM})$ and incubated $\left(1\right.$ hour, $\left.42^{\circ} \mathrm{C}\right)$. At the end of transcription, the enzyme was denaturated $\left(95^{\circ} \mathrm{C}, 10\right.$ minutes) in dry bath and the volume was elevated to $100 \mu \mathrm{L}$.

To specific amplification of cDNAs, all primers were aligned in exons separated by long introns or in exon-exon boundaries to preclude amplification of genomic DNA. All amplifications had one first cycle of denaturation $\left(94^{\circ} \mathrm{C}, 5\right.$ minutes) followed by $25-35$ cycles $\left(94{ }^{\circ} \mathrm{C}, 45\right.$ seconds; $60{ }^{\circ} \mathrm{C}, 45$ seconds; $72{ }^{\circ} \mathrm{C}$, 90 seconds; $72{ }^{\circ} \mathrm{C}, 7$ minutes). The primer sequences were: GAPDH sense- CCA CCC ATG GCA AAT TCC ATG GCA and antisense -TCT AGA CGG CAG GTC AGG TCC ACC, IL-6 sense - ATG TAG CCG CCC CAC ACA GA and antisense - CAT CCA TCT TTT TCA GCC AT; IL-10 sense -GCC TAA CAT GCT TCG AGA TC and antisense -TGA TGT CTG GGT CTT GGT TC, TNF- $\alpha$ sense-CAC CAT GAG CAC TGA AAG CA and antisense -CTT GAA GAG GAC CTG GGA GT, granulysin sense -CAG ATG GGT GGC CAG TGG CT and antisense - TGA CCT TCA ATG GTA GTA CCA. The reaction products were qualitatively ascertained by the size of the PCR product analyzed by agarose gel electrophoresis stained with ethidium bromide: GAPDH-566 bp; IFN $\gamma-465$ bp; TNF $\alpha-426$ bp; IL-6189 bp; IL-10-205 bp; granulysin-334 bp

\section{RESULTS AND DISCUSSION}

Usually, in the CHF patients echocardiographic variables give important informations concerning their 
clinical conditions. In fact, for evaluation of the left ventricular function in CHF patients, the echocardiogram is already established as an efficient and necessary method. In our study, anamnesis and clinical examination associated to echocardiography were able to give basic information concerning etiopathogenesis and physiopathology of the syndrome, as well as to address the therapeutic plan. In addition, the inflammatory immune activation is a new boarding in the clinical follow-up of these patients. At this moment, it is acceptable the correlation between the NYHA functional class and TNF- $\alpha$ levels in CHF patients, in which levels would increase as well as the functional class. In those cases, CHF severity and prognosis could be evaluated through the quantification of these markers. In Brazil, there are few studies about this subject.

In the presented study, after anamnesis and clinical examination, patients were classified according to NYHA functional class [I (P1b, P2b, P5, P8 and P12b), II (P7, P10 and P12a), III (P1a, P2a, P3a and P9), IV $(\mathrm{P} 3 \mathrm{~b}, \mathrm{P} 3 \mathrm{c}$ and $\mathrm{P} 11)]$. The main signals detected in the studied groups were: third and fourth heart sound, arrhythmia, heart murmurs, peripheral edema, hepatomegaly, lung crackles, jugular vein distension and Hepatojugular reflux. The main CHF etiology detected in the patients was hypertension, excepting P2 that had peripartum cardiomyopathy. Furthermore, some of these patients had alcoholism (P3, P7), diabetes mellitus (P7, P9 and P10) or isquemic cardiopathy (P9 and $\mathrm{P} 10)$. In addition, the recruited groups showed a heterogeneous distribution (\%) in relation to sex $(\delta / Q)$ : control (71/29), NYHA class I (60/40), NYHA class II (66/33), NYHA class III (50/50) and NYHA class IV $(100 / 0)$. ventricular fractional shortening also showed an inversely proportional tendency to the CHF gravity (Table I). This analysis was also a good parameter to distinguish between patients with CHF in comparison to controls $(\mathrm{p}=0.0014)$. The ejection fraction directly relates to fractional shortening and its impairing, and it is also responsible for evident and very easily perceptible symptoms for the patient, as dyspnea, which has relevance for functional classification by NYHA.

On the other hand, the analysis of final diastolic volume uncorrected (FDV) and corrected (cFDV) shown high dispersion values among the patients, without apparently association with functional classes, (Table I). However, the media values of FDV (208 \pm 63 $\left.\mathrm{cm}^{3}\right)$ and cFDV $\left(125 \pm 27 \mathrm{~cm}^{3} / \mathrm{m}^{2}\right)$ were clearly higher than the control group, $p=0.00003$ and $p=0.0000014$, respectively. The same has occurred with the Final Diastolic Diameter uncorrected (FDD) and corrected (cFDD), and in such analysis the medium values were more homogeneous. In spite of the absence of correlation of FDD and cFDD medium values with NYHA functional class, there is a difference between control group) and CHF patients (FDD $=4.0 \pm 0.4 \mathrm{~cm}$, cFDD $=6.2 \pm 0.9 \mathrm{~cm} / \mathrm{cm}^{2}$ ), which seems to be a good discriminator between control and patient groups: FDD, $\mathrm{p}=0.00018$ and $\mathrm{cFDD}, \mathrm{p}=0.0002$. It has been demonstrated that measures of the systolic function, including fractional shortening and final diastolic volume, contain prognostic information ${ }^{15}$, what was also suggested in the present work

Similarly, Cardiac Indexes (CI) had no correlation with the NYHA patients class (Table I). However, the CI media value of the patients $\left(5.1 \pm 1.6 \mathrm{~L} / \mathrm{min} . \mathrm{m}^{2}\right)$ were approximately two times higher than that in the

Table I: Echocardiographic parameters from CHF analyzed patients

\begin{tabular}{|c|c|c|c|c|c|c|c|c|}
\hline \multirow{2}{*}{$\begin{array}{l}\text { Studied } \\
\text { groups }\end{array}$} & \multicolumn{8}{|c|}{ Echocardiograph data } \\
\hline & $\begin{array}{l}\mathrm{EF} \\
(\%)\end{array}$ & $\begin{array}{c}\text { LVFS } \\
(\%)\end{array}$ & $\begin{array}{l}\text { FDV } \\
\left(\mathrm{cm}^{3}\right)\end{array}$ & $\begin{array}{c}\text { cFDV } \\
\left(\mathrm{cm}^{3} / \mathrm{m}^{2}\right)\end{array}$ & $\begin{array}{l}\text { FDD } \\
(\mathrm{cm})\end{array}$ & $\begin{array}{c}\mathrm{cFDD} \\
\left(\mathrm{cm} / \mathrm{cm}^{2}\right)\end{array}$ & $\begin{array}{c}\mathrm{CI} \\
\left(\mathrm{L} / \mathrm{min} \cdot \mathrm{m}^{2}\right)\end{array}$ & $\begin{array}{c}\mathrm{SI} \\
\left(\mathrm{mL} / \mathrm{m}^{2}\right)\end{array}$ \\
\hline Control & $75 \pm 10$ & $40 \pm 10$ & $93.0 \pm 19$ & $50 \pm 11$ & $2.4 \pm 0.3$ & $4.4 \pm 0.4$ & $2.7 \pm 0.58$ & $37 \pm 7.6$ \\
\hline I & $78 \pm 10$ & $33 \pm 10$ & $169 \pm 20$ & $113 \pm 12$ & $6.0 \pm 0.4$ & $3.6 \pm 0.4$ & $4.3 \pm 2.0$ & $62 \pm 20$ \\
\hline ПI & $50 \pm \mathrm{ND}$ & $25 \pm \mathrm{ND}$ & $213 \pm N D$ & $135 \pm \mathrm{ND}$ & $6.0 \pm \mathrm{ND}$ & $4.3 \pm N D$ & $5.0 \pm N D$ & $50 \pm \mathrm{ND}$ \\
\hline III & $38 \pm 04$ & $20 \pm 03$ & $172 \pm 20$ & $135 \pm 14$ & $6.3 \pm 0.4$ & $4.7 \pm 0.8$ & $5.0 \pm 0.7$ & $73 \pm 09$ \\
\hline ГV & $37 \pm N D$ & $18 \pm N D$ & $290 \pm N D$ & $160 \pm N D$ & $6.5 \pm \mathrm{ND}$ & $4.0 \pm N D$ & $4.0 \pm N D$ & $50 \pm N D$ \\
\hline
\end{tabular}

WYHA fimctional class (I, II, II and IV); Ejection Fraction (EF); Final Diastolic Vohme moomected (FDV) and comrected (cFDV); Final Diastolic Diameter (FDD) and corrected (c FDD); Candiax Indioes (CI); Systolic Indioes (SI); Left Ventricular Fractional Shortening (L VFS); Standard deviation ( \pm ) not deternined (HD).

The echocardiographic variables were determined, in order to compare these groups. We have detected that the ejection fraction (EF) of the control group has shown a mean value $>70 \%$, while for the patients it has shown progressively minor values according to the increase of NYHA functional class (Table I). The analysis of EF between CHF patients (all the functional classes together) and the control group has shown a statistical difference $(p=0.0005)$. Interestingly, the left control group, showing statistical significance $(\mathrm{p}=$ 0.0006). The results did not shown association between Systolic Indexes (SI) and the functional classes, although these parameters indicated differences $(\mathrm{p}=$ $0.0002)$ between the patient $\left(57.8 \pm 11 \mathrm{~mL} / \mathrm{m}^{2}\right)$ and control groups. It is import to emphasize that this fact did not occur with other echocardiographic parameters analyzed. Such variations are according to the adaptation mechanisms in the CHF and also reflect the consequences of the myocardium dysfunction, as lesser 
ejection fractions among the patients. It is important to observe that the echocardiogram is an image method and the modified values of volume and diameter were shown, exactly for the patients of NYHA class I, who do not have symptoms or limitation of its activities.

Cytokines expression in patient and control groups sera were measured and compared. The performed ELISA for determination of TNF- $\alpha$ levels showed this cytokine is present in the patient P2b NHYA class I $(12.5 \mathrm{pg} / \mathrm{mL})$. The other patients did not show detectable levels that cytokine $(<0.1 \mathrm{pg} / \mathrm{mL})$. Curiously, two individuals from the control group revealed high serum levels of TNF- $\alpha$ (C3, $12.0 \mathrm{ng} / \mathrm{mL}$ and C7, $160 \mathrm{pg} / \mathrm{mL}$ ); differently of other samples that had TNF$\alpha$ levels below the detection limit. Part of these data could be confirmed by RT-PCR assay, given that patients $\mathrm{P} 2 \mathrm{~b}$ and $\mathrm{P} 3$ (22\%), and $\mathrm{C} 2$ from the control group $(14.2 \%)$ were positive for detection of TNF- $\alpha$ mRNA (Table II). Our data show the inconsistency of the detection of TNF- $\alpha$ (mRNA or protein) for the diagnosis of $\mathrm{CHF}$ clinical cases. Since such cytokine is one of the first secreted molecules during immune activation it is very difficult to infer if recent infections, mainly for the control group, could be altering the expression of the gene. Despite of this inconsistency, other studies had already verified that patients with lower plasmatic levels of TNF- $\alpha(6.5 \mathrm{pg} / \mathrm{ml})$ had better prognostic than patients with higher levels ${ }^{5}$.

Table II: Qualitative cytokine expression in peripheral blood mononuclear cells from congestive heart failure patients and control group.

\begin{tabular}{lcccccc}
\hline \multicolumn{1}{c}{ Subjects } & N & GAPDH & TNF-? & IL-10 & IL-6 & Granulysin \\
\hline CHF Patients & 9 & $9 / 9^{100 \%}$ & $2 / 9^{22 \%}$ & $0 / 9$ & $2 / 7^{28.5 \%}$ & $7 / 9^{78 \%}$ \\
\hline Controls & 7 & $7 / 7^{100 \%}$ & $1 / 7^{14.2 \%}$ & $0 / 7$ & $1 / 7^{14.2 \%}$ & $1 / 5^{20 \%}$ \\
\hline
\end{tabular}

The IFN- $\gamma$ was another cytokine involved in natural immunity which was also quantified in serum samples. In this case, it was possible to detect this cytokine in patient 1 , when he was in NHYA class II $(\mathrm{P} 1 \mathrm{a}=20 \mathrm{ng} / \mathrm{mL})$ and then, in a second moment, in NYHA class I $(\mathrm{P} 1 \mathrm{~b}=90 \mathrm{ng} / \mathrm{mL})$. The $\mathrm{P} 11$ patient showed elevated levels of this cytokine $(100 \mathrm{ng} / \mathrm{mL})$, and he was in NYHA class IV. The IFN- $\gamma$ levels did not show any tendency with functional class of these patients. The other patients did not show detectable levels of this cytokine, by using the chosen method $(<0.1 \mathrm{ng} / \mathrm{mL})$. Concerning the control group, two people revealed detectable levels of IFN- $\gamma$ C7 $(50 \mathrm{ng} / \mathrm{mL})$ e C6 $(65 \mathrm{ng} / \mathrm{mL})$; while the other individuals maintained below of the method detection limit (data not showed).

The present study also proposed the mRNA detection for IL-10 and IL-6 cytokines in PBMCs, in order to evaluate the potential differences in the CHF patients as compared to a control group (Table II). Neither of the tested samples was positive for IL-10 nor IL-6 mRNA expression, in our experimental conditions.
Although, it has been described high levels of IL-6 expression in patients with poor ejection fraction ${ }^{10}$.

In the qualitative assay using dot-ELISA it was possible to reveal the presence of the sTNFR-I, preferentially in sera of the patients with CHF. This fact was confirmed since sera from the control group did not show any precipitation signal of antigen/antibody complex (figure). In addition, it was also possible to demonstrate a recognition signal with increasing intensity according to the functional class: NYHA class IV > NYHA class III > NYHA class II > NYHA class I. It is known that the high sTNFR-I, but not sTNFR-II, is an excellent marker of CHF patients with poor prognostic value ${ }^{15}$. In a certain way, the same was observed here, since sTNFR-II was detected in all serum samples assayed from the patients, without association with functional group (data not showed).

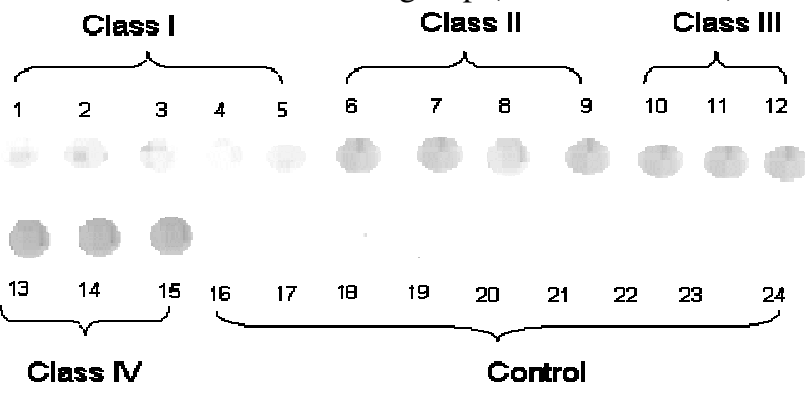

Figure: sTNFR-I detection in the serum. The serum samples (10mg) were adsorbed in nitrocellulose membrane and the sTNFR-I revealed by immunoenzymatic assay using an specific monoclonal antibody $(1: 1000)$. The inmunoenzym [class I - 1 (P1b), 2 (P2b), 3 (P5), 4 (P8) and 5 (P12b); class II - 6 (P1), 7 (P7), 8 (P10), 9 (P12); class - III 10 (P12), 11 (P3), 12 (P9) and class IV-13 (P3b), 14 (P3c), 15(P11)] and the control group [17 (C1), 18 (C2), 19 (C3), 20 (C4), 21 (C5), 22 (C6), 23 (7)]. The points of application 16 and 24 correspond to negative controls of the reaction, where PBS was applied

Although it has been described in literature that TNF- $\alpha$ can quantitatively be related to the functional class, the present results had not demonstrated this trend. The majority of the patients showed values below of the level of detection for the used method. Only one patient, NHYA class I, showed a comparable level to that described in literature ${ }^{2}$. Moreover, it is possible that this cytokine is being expressed inside the myocardium, what hinders the quantification in the peripheral circulation. The myocyte produces this cytokine due the volemic overload and to stress haemodynamic ${ }^{16}$ while skeletal muscle, in hypoxia, may produce $\mathrm{TNF}-\alpha$. In addition, the expression of the TNF- $\alpha$ and IFN- $\gamma$ in patients sera could be caused by the stimulation of leukocytes after bacterial translocation to circulation in the patients with CHF. Also, the sTNFR-I detection in crescent intensity according to the functional class is an indicative that TNF- $\alpha$ cytokine was present in some point of the patients circadian cycle. The detection constancy of STNFR-I in all CHF patients may explained by the fact that these molecules are more stable and present a longer half-life ${ }^{11}$.

One new find described in this work was the detection of granulysin mRNA in PBMC of CHF cases. 
In spite of the few cases analyzed, granulysin mRNA expression was positive in the majority of the patients (78 \%) as compared to controls ( $20 \%)$. Granulysin is a cytolytic molecule found in human Cytotoxic $\mathrm{T}$ lymphocytes and natural killer cells with broad activity against microbes and tumors. It was demonstrated the highly diagnostic value of intragraft granulysin by monitoring renal transplant patients, making this approach suitable for detecting ongoing rejection processes ${ }^{17}$. Although the granulysin expression is indicative of good prognostic, especially in patients with cancer ${ }^{18}$, our results did not show any association with severity CHF (data not showed). On the other hand, the present data suggest the granulysin as potential marker in CHF might be used as novel strategy for the characterization of CHF cases itself.

\section{CONCLUSION}

Finally, it makes sense that in our study the echocardiography variables as EF and LVFS and sTNFR-I evaluated have been correlated with clarity in distinction of functional classes, collaborating in the description of the stratification in chronic heart failure $^{19}$. The other echocardiography and immunological variables assayed in this work only showed differences between the control and the CHF patient group, independent of the functional class. In addition, this study reinforces that not only soluble markers in the sera like sTNFR-I, but also mRNA expression assayed in PBMCs such as granulysin could be targets for diagnostic and new therapy in additional to conventional cardiovascular treatment in CHF.

\section{ACKNOWLEDGMENTS}

We thank Dr Evandro. T. Mesquita, Dr José Antônio P. Sá and Dr Bernardo A.S Pereira for critical review of the manuscript. This investigation was supported by FAPERJ.

\section{REFERENCES}

1. Packer M, Carver JR, Rodeheffer RJ, Ivanhoe RJ, DiBianco R, Zeldis SM, Hendrix GH, Bommer WJ, Elkayam U, Kukin ML, 1991. Effect of oral milrinone on mortality in severe chronic heart failure. The PROMISE Study Research Group. N Engl J Med, 325:1468-1475.

2. Levine B, Kalman J, Mayer L, Fillit HM, Packer M., 1990.Elevated circulating levels of tumor necrosis factor in severe chronic heart failure. $\mathrm{N}$ Engl J Med, 323: 236-241.

3. Testa M, Yeh M, Lee P, Fanelli R, Loperfido F, Berman JW, LeJemtel TH., 1996.Circulating levels of cytokines and their endogenous modulators in patients with mild to severe congestive heart failure due to coronary artery disease or hypertension. J Am Coll Cardiol, 28: 964-671.
4. Damås JK, Gullestad L, Aukrust P. Cytokines as new treatment targets in chronic heart failure. Curr Control Trials Cardiovasc Med. 2001, 2: 271-277.

5. Bozkurt B, Kribbs SB, Clubb FJ Jr, Michael LH, Didenko VV, Hornsby PJ, Seta Y, Oral H, Spinale FG, Mann DL., 1998. Pathophysiologically relevant concentrations of tumor necrosis factoralpha promotes left ventricular dysfunction and remodeling in rats. Circulation, 97:1382-1391.

6. Gulick T, Chung MK, Pieper SJ, Lange LG, 1989. Schreiner GF. Interleukin 1 and tumor necrosis factor inhibit cardiac myocyte beta-adrenergic responsiveness. Proc Natl Acad Sci USA, 86: 6753-6757.

7. Finkel MS, Oddis CV, Jacob TD, Watkins SC, Hattler BG, Simmons RL, 1992. Negative inotropic effects of cytokines on the heart mediated by nitric oxide. Science, 257: 387-389.

8. Pulkki KJ., 1997.Cytokines and cardiomyocyte death. Ann Med, 29:339-343.

9. Birks EJ, Burton PB, Owen V, Mullen AJ, Hunt D, Banner NR, Barton PJ, Yacoub MH., 2000.Elevated tumor necrosis factor-alpha and interleukin-6 in myocardium and serum of malfunctioning donor hearts. Circulation, 102:352-358.

10. Plenz G, Song ZF, Reichenberg S, Tjan TD, Robenek H, Deng MC., 1998.Left-ventricular expression of interleukin-6 messenger-RNA higher in dilated than in ischemic cardiomyopathy. Thorac Cardiovasc Surg, 46: 213-216.

11. Ferrari R, Bachetti T, Confortini R, Opasich C, Febo O, Corti A, Cassani G, Visioli O., 1995.Tumor necrosis factor soluble receptors in patients with various degrees of congestive heart failure. Circulation, 92:1479-1486.

12. Colquhoun MC, Waine C, Monaghan MJ, Struthers AD, Mills PG., 1995.Investigation in general practice of patients with suspected heart failure. How should the essential echocardiographic service be delivered? Br Heart J, 74: 335-336.

13. Mosterd A, de Bruijne MC, Hoes AW, Deckers JW, Hofman A, Grobbee DE., 1997.Usefulness of echocardiography in detecting left ventricular dysfunction in population based studies (The Rotterdam Study). Am J Cardiol, 79: 103-111.

14. Wang M, Yip GWK, Wang AYM, Zhang Y, Ho PY, Tse MK, Yu CM, Sanderson JE., 2005.Tissue Doppler imaging provides incremental prognostic value in patients with systemic hypertension and left ventricular hypertrophy J Hypertension, 23:183-191. 
15. Kapadia SR, Oral H, Lee J, Nakano M, Taffet GE, Mann DL., 1997. Hemodynamic regulation of tumor necrosis factor-alpha gene and protein expression in adult feline myocardium. Circ Res., 81: 187-95.

16. Niebauer J, Volk HD, Kemp M, Dominguez M, Schumann RR, Rauchhaus M,Poole-Wilson PA, Coats AJ, Anker SD., 1999. Endotoxin and immune activation in chronic heart failure: a prospective cohort study. Lancet, 353: 1838-1842.
17. Kotsch K, Mashreghi MF, Bold G, Tretow P, Beyer J, Matz M, Hoerstrup J, Pratschke J, Ding R, Suthanthiran M, Volk HD, Reinke P., 2004. Enhanced granulysin mRNA expression in urinary sediment in early and delayed acute renal allograft rejection. Transplantation, 77: 1866-1875.

18. Clayberger C, Krensky AM., 2003. Granulysin. Curr Opin Immunol, 15: 560-565.

19. Cowburn PJ, Cleland JG, Coats AJ, Komajda M., 1998; Risk stratification in chronic heart failure. Eur Heart J, 19: 696-710. 